\title{
JUSTICE SCALIA AND THE ART OF RHETORIC
}

\section{Jeffrey M. Shaman*}

Throughout his tenure as a Supreme Court justice, Antonin Scalia has suffered a great deal of scathing criticism. He has been castigated as mean-spirited, intolerant, disingenuous, rigid, unprincipled, partisan, reactionary, simplistic, and misogynistic. His views about the Constitution have been described as troubling, alarming-even chilling-and his philosophy of originalism has been dismissed as a fraud. But give credit where credit is due: he is one helluva stylist. Nicknamed "El Niño" after the calamitous oceanic phenomena that can create havoc throughout the globe, Justice Scalia has demonstrated his rhetorical skills in opinion after opinion, leaving no doubt that he is a master of metaphor and other belletristic flourishes. The septuagenarian jurist wields a wicked poison pen when the spirit moves him, peppers his opinions with creative lists of examples, and is wont to drop in a bon mot here and there, not to mention an arcane foreign phrase that sends lesser mortals rushing to their Latin, French, or German dictionaries. Other justices on the High Court have displayed enviable writing skills. A fewLouis Brandeis and Robert Jackson come to mind-were able on occasion to write with exceptional grace and beauty. Justice Holmes, himself the son of an esteemed writer, had a special gift for conceiving aphorisms. Justice Scalia's talent, however, lies in a different direction, distinguished by a flair for being strikingly sharp and clever.

\footnotetext{
* Vincent de Paul Professor of Law, DePaul University College of Law. The author wishes to thank Susan Shaman for the expert editorial assistance she provided.

1. Probably the most famous of Holmes" aphorisms is his remark that "The 14th Amendment does not enact Mr. Herbert Spencer's Social Statics." Lochner v. New York, 198 U.S. 45, 75 (1905) (Holmes, J., dissenting). Also especially noteworthy is his observation that "The common law is not a brooding omnipresence in the sky." Southern Pacific Co. v. Jensen, 244 U.S. 205, 222 (1917) (Holmes, J., dissenting). Sadly, he also penned the infamous "Three generations of imbeciles are enough." Buck v. Bell, 274 U.S. 200, 207 (1927).
} 
Not one to avoid confrontation, Justice Scalia is notorious for his verbal barbs, frequently directed at his colleagues on the Supreme Court. Hein v. Freedom from Religion Foundation, Inc. offers a recent example of Justice Scalia's gift for skewering his colleagues. In Hein he begins, tellingly, with a pugilistic metaphor, followed by a series of censorious adjectives: "[L]aying just claim to be honoring stare decisis requires more than beating Flast [v. Cohen] to a pulp and then sending it out to the lower courts weakened, denigrated, more incomprehensible than ever, and yet somehow technically alive." ${ }^{2}$ A few sentences later, he delivers the zinger, decked out in another, but more imaginative, metaphor: "We had an opportunity today to erase this blot on our jurisprudence, but instead have simply smudged it." 3

As his opinion in Hein illustrates, Justice Scalia is particularly adept at crafting a neat phrase, especially when it can be used to disparage another justice. Other examples of this facility are legion. Dissenting in Sykes v. United States, he dismissed what Justice Kennedy had written for the Court's majority as a "tutti-frutti opinion." ${ }^{4}$ In FEC $v$. Wisconsin Right to Life, he accused Chief Justice Roberts, who authored the Court's principal opinion, of engaging in "faux judicial restraint." In Michigan v. Bryant, he lectured Justice Sotomayor for writing a majority opinion that, "[i]nstead of clarifying the law," made the Court "the obfuscator of last resort." And in Barnes v. Glen Theatre, throwing brevity to the wind, he castigated the dissenters for adopting a "Thoreauvian 'you-maydo-what-you-like-so-long-as-it-does-not-injure-someone-else' beau ideal ...."

Evidently, Justice Scalia is practiced at using abundant hyphenation in order to craft elongated compound phrases. $\mathrm{He}$ repeated the trick in Planned Parenthood of Southeastern Pennsylvania $v$. Casey, scolding other justices for adopting a "keep-what-you-want-and-throw-away-the-rest" version of stare decisis. ${ }^{8}$ It is a snazzy device that shows off his inventiveness, albeit at the risk of being a bit too cute.

2. Hein v. Freedom from Religion Foundation, Inc., 551 U.S. 587, 636 (Scalia, J., concurring).

3. Id. at 637.

4. 131 S. Ct. 2267, 2285 (2011) (Scalia, J., dissenting).

5. 551 U.S. 449, 499 n.7 (2007) (Scalia, J., concurring).

6. 131 S. Ct. 1143,1168 (2011) (Scalia, J., dissenting).

7. 501 U.S. 560, 575 (1991) (Scalia, J., concurring).

8. 505 U.S. 833, 993 (1992) (Scalia, J., dissenting in part). 


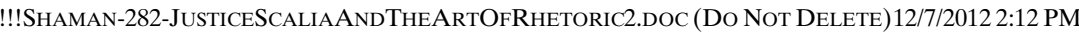

Cultured and sophisticated though he may be, Justice Scalia is not above using a cliché when it suits his purposes, as it did in NEA v. Finley.' In that case, the Court's majority gave a narrowing construction to a federal statute in order to save its constitutionality. Although Justice Scalia concurred in the judgment upholding the statute, he thought that the Court's narrow construction of the statute vitiated its meaning to such an extent as to render it ineffectual. Reacting to the majority opinion, he declaimed that " $[\mathrm{t}]$ he operation was a success but the patient died" quite to the point that he wanted to make. On occasion Justice Scalia is able to transcend a cliché's triteness by giving it a new twist, as he did in Pleasant Grove City v. Summum, where he declared that " $[\mathrm{t}]$ he city ought not fear that today's victory has propelled it from the Free Speech Clause frying pan into the Establishment Clause fire."11

It comes as no surprise that the erudite Justice Scalia is fond of allusions, literary or otherwise. What is perhaps more surprising is his playful penchant for juxtaposing incongruous examples. Thus, in Hill v. Colorado, discussing the First Amendment standard that a statute must be narrowly tailored to achieve it purposes, Scalia quipped that to the Court's majority, "narrow tailoring must refer not to the standards of Versace, but to those of Omar the tentmaker." 12 Apparently a renaissance man versed in history as well as fashion and literature, the Justice once reproached his colleagues for siding with the knights "Templar" rather than with the peasant "villeins."13 Cinema, too, is within his domain of knowledge; witness his dig in NASA v. Nelson that "[i]t is past time for the Court to abandon this Alfred Hitchcock line of our jurisprudence." ${ }^{14}$

Another literary flourish that can be found animating the Justice's opinions is the eponym, that is, a word derived from a person's name to signify a characteristic associated with that person. The person may be real, fictional, or-so much the better to the Scalian way of thinking-mythical. In Sykes v. United States, the learned Justice described a provision in a

9. 524 U.S. 569 (1998)

10. Id. at 590 (Scalia, J., concurring).

11. 555 U.S. 460, 482 (2009) (Scalia, J., concurring).

12. 530 U.S. 703, 749 (2000) (Scalia, J., dissenting).

13. Romer v. Evans, 517 U.S. 620, 652 (1996) (Scalia, J., dissenting).

14. 131 S. Ct. 746, 767 (2011) (Scalia, J., concurring). 


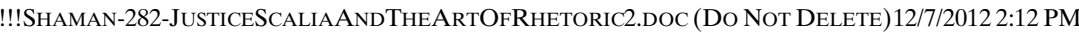

federal statute as the "Delphic residual clause,"15 an eponymous allusion to the Delphic Oracle, whose gibberish-like pronouncements were reformulated by priests as enigmatic prophecies. In Planned Parenthood of Southeastern Pennsylvania $v$. Casey, he denounced the position articulated by other justices as a "Nietzschean vision," 16 alluding of course to Friedrich Nietzsche, the 19th century German philosopher who proclaimed the death of God and who conceived the notion of the Übermensch-an extraordinary individual who transcends the limits of traditional morality to live purely by the will to power. There is no need to mention here that Nietzsche's philosophy is absolute anathema to Justice Scalia, who on several occasions has championed the authority of government to preserve traditional moral values. ${ }^{17}$

Although he has argued vehemently that the Court has no business using foreign law to bolster its decisions interpreting the Constitution, ${ }^{18}$ Justice Scalia is happy to use catchy foreign phrases to spice up his own opinions. Dissenting from the Court's decision in Romer v. Evans striking down an amendment to the Colorado constitution that denied gay and lesbian persons the right to seek legal protection from discrimination, Justice Scalia fumed that "The Court has mistaken a Kulturkampf for a fit of spite." ${ }^{\prime 19}$ Dissenting in Planned Parenthood of Southeastern Pennsylvania $v$. Casey, he played a variation on a theme by evoking a Latin phrase, Pax Romana (a long period of peace in the Roman Empire) and giving it a creative twist in reference to Roe v. Wade, to come up with a sharp rebuke to his colleagues on the Court who refused to see the light: "And by keeping us in the abortion-umpiring business, it is the perpetuation of that disruption, rather than of any Pax Roeana, that the Court's new majority decrees. ${ }^{\prime 20}$ Interestingly, while the phrase Pax Romana

15. 131 S. Ct. 2267, 2284 (Scalia, J., dissenting).

16. 505 U.S. 833, 996 (1992) (Scalia, J., dissenting in part).

17. See, e.g., Barnes v. Glen Theatre, Inc., 501 U.S. 560, 575 (1991) (Scalia, J., concurring); Romer, 517 U.S. at 644-53 (Scalia, J., dissenting).

18. See Lawrence v. Texas, 539 U.S. 558, 598-99 (2003) (Scalia, J., dissenting); Justice Scalia on Foreign Law and the Constitution, OPINIO JURIS, Feb. 22, 2006, http://lawofnations.blogspot.com/2006/02/justice-scalia-on-foreign-law-and.html.

19. Romer v. Evans, 517 U.S. at 636 (1996) (Scalia, J., dissenting). "Kulturkampf" translates literally as "culture struggle." The phrase was originally used as a political slogan in reference to the ongoing struggle that occurred in the 1870 s between the Roman Catholic Church and the German government for control over school and church appointments and civil marriage. See Kulturkampf Definition, DictionARY.COM, http:// dictionary.reference.com/ browse/Kulturkampf?s=t (last visited Apr. 22, 2012).

20. Casey, 505 U.S. at 996 (Scalia, J., dissenting in part). 
initially denoted the 207 year period of peace inaugurated by Emperor Augustus Caesar during the Roman Empire, ${ }^{21}$ it also is the name of an international organization of Catholic students and academics, ${ }^{22}$ as well as the title of a short comic book series by Jonathan Hickman that depicts a group of time travelers sponsored by the Vatican who return to 4th century Rome in an attempt to change the past in order to save the future. ${ }^{23}$ It is no small irony that Hickman's plan for safeguarding the future is exactly the inverse of Scalia's originalist constitutional ideology, according to which the Constitution should be interpreted according to its original meaning at the time when it was first enacted. Whereas Hickman believes that the past must be altered, Scalia insists that it must be perpetuated; whereas Hickman would happily reconstruct the past, Scalia would enshrine it.

Justice Scalia's Latinate word play in Casey reveals a certain pedantic hauteur, if not outright condescension. A similar disposition is also on display in National Endowment for the Arts $v$. Finley, a case challenging the constitutionality of a Congressional amendment directing the Chairperson of the NEA to take into consideration "general standards of decency" in judging grant applications. ${ }^{24}$ The challenge was brought by several performance artists, including Karen Finley, a controversial figure perhaps best known for a performance piece in which she portrays a sexual assault by stripping to the waist and smearing chocolate on her breasts. ${ }^{25}$ Justice Scalia's dismissive response to the likes of Ms. Finley was a combination of sarcasm and condescension, delivered in not one, but two nifty foreign phrases: "Avant-garde artistes such as respondents remain entirely free to epater les bourgeois; they are merely deprived of the additional satisfaction of having the bourgeoisie taxed to pay for it." ${ }^{26}$ One suspects that Justice Scalia chose those phrases very carefully, well-attuned to their subtle shades of meaning. "Avant-garde," a relatively familiar phrase, translates literally

21. See Pax Romana Definition, BRITTANICA ACADEMIC EDITION, http://www. britannica.com/EBchecked/topic/447447/Pax-Romana (last visited Apr. 22, 2012).

22. See generally International Catholic Movement for Intellectual \& Cultural Affairs, PAXROMANA.ORG, http://paxromanausa.org/default.aspx.

23. See generally JONATHAN HICKMAN, PAX ROMANA (2009) (collecting the entire comic series into a single paperback volume).

24. 524 U.S. 569,569 (1998).

25. Id. at 596 n.2 (Scalia, J., concurring).

26. Id. at 595-96 (Scalia, J., concurring). 
from the French as "advance guard" or "vanguard." ${ }^{27}$ When used as an adjective, it describes something that is innovative or experimental, especially in the arts. ${ }^{28}$ For some, this may be high praise, but to a conservative soul such as Justice Scalia, who venerates the past and abhors change, it is anything but. "Artiste," of course, is French for "artist." 29 But in English the primary definition of "artiste" is "a skilled adept public performer," ${ }^{30}$ which is something less than an artist. In fact, the Oxford English Dictionary notes that the word was reintroduced from French to English due to the modern tendency to restrict "artist" to those engaged in the fine arts." ${ }^{31}$ According to the Columbia Guide to Standard English, to describe someone as an artiste "may once have been a compliment," but as used today it is "facetious, deliberately overblown, and uncomplimentary." ${ }^{, 2}$ Moving on and (I admit) at this point having to consult my French dictionary, I learned that "epater les bourgeois" means "to shock the middle classes," 33 but other sources explain it as "an ironic French phrase currently used to describe shallow attempts at getting noticed through art." ${ }^{34}$ So, there you have the quintessential Scalia: poison pen, sarcasm, and irony encased in two cunning foreign phrases, all wrapped up and ready to go in a single sentence.

Appointed to the Supreme Court in 1986, Justice Antonin Scalia has proven over the years that he possesses exceptional rhetorical skills. Whatever criticism may be leveled against him, surely he cannot be accused of being artless. Indeed, his finest achievement may be that he writes with virtuosity.

27. See Avant-garde Definition, DictiONARY.COM, http://dictionary.reference.com/ browse/avant-garde (last accessed Apr. 22, 2012).

28. Id.

29. See Artiste Definition, DictionARY.COM, http://dictionary.reference.com/ browse/artiste?s=t (last visited Apr. 22, 2012).

30. Artiste Definition, MERRIAM-WEBSTER.COM, http://www.merriam-webster.com/ dictionary/artiste (last visited Apr. 22, 2012).

31. Artiste Definition, OXFORD ENGLISH DICTIONARY, http://www.oed.com/view/ Entry/ 11239?redirectedFrom=artiste\#eid (last visited Apr. 22, 2012).

32. Kenneth G. Wilson, The Columbia Guide to Standard American ENGLISH 40 (1993).

33. MERRIAM-WEBSTER.COM, http://www.merriam-webster.com/dictionary/\%C3\% A9pater\%20le\%20bourgeois (last accessed Apr. 22, 2012).

34. See, e.g., French Words and Phrases, DUCKDUCKGo, http://duckduckgo. com/1/c/French_words_and_phrases (last visited Apr. 12, 2012). 